\title{
The two forms of capitalism: developmentalism and economic liberalism
}

\author{
As duas formas de capitalismo: \\ desenvolvimentista e liberal econômico
}

LUIZ CARLOS BRESSER-PEREIRA*»

\begin{abstract}
RESUMO: Este artigo argumenta que o Estado e o mercado são as principais instituições que regulam o capitalismo e, consequentemente, que a forma de organização econômica e política do capitalismo ou é desenvolvimentista ou é liberal. O artigo define Estado desenvolvimentista, o relaciona com a formação de uma coalizão de classe desenvolvimentista, e assinala que o capitalismo nasceu desenvolvimentista no mercantilismo, tornou-se liberal no século XIX e, depois de 1929, tornou-se novamente desenvolvimentista, mas agora democrático e social. Todas as revoluções industriais e capitalistas ocorreram no quadro do desenvolvimentismo, onde o Estado coordena o setor não competitivo da economia e os cinco preços macroeconômicos (que o mercado é incapaz de tornar “certos”), enquanto o mercado coordena o setor competitivo. Na década de 1970, uma crise abriu espaço para uma forma de capitalismo neoliberal ou financeiro-rentista. Desde a crise financeira global de 2008, a hegemonia neoliberal chegou ao fim e, a partir de então, estamos passando por um período de transição.
\end{abstract}

PALAVRAS-CHAVE: Capitalismo; desenvolvimentismo; liberalismo econômico; capitalismo financeiro-rentista.

ABSTRACT: This paper argues that the state and the market are the main institutions regulating capitalism, and, correspondingly, that the form of the economic and political coordination of capitalism will be either developmental or liberal. It defines the developmental state, relates it to the formation of a developmental class coalition, and notes that capitalism was born developmental in its mercantilist phase, turned liberal in the nineteenth century, and, after 1929, became once again developmental, but, now, democratic and progressive. All industrial and capitalist revolutions took place within the framework of

\footnotetext{
* Emeritus professor of Fundação Getúlio Vargas. E-mail: bresserpereira@gmail.co.

$\diamond$ This paper was originally presented to 2013 SASE conference, in Milan. I express my thanks to Robert Boyer, Ben Ross Schneider, Marcus Ianoni, Claudio Gonçalves Couto, Hideko Magara, Hiroshi Nishi, Eunmi Choi, Ilan Bizberg, Kurt von Mettenheim, Pierre Salama, André Singer, Cícero Araújo, Cristina Helena Pinto de Mello, Eleutério Prado, José Márcio Rego, Luiz Felipe Alencastro and Nelson Marconi, who commented on this paper and contributed to its improvement. Submetido: 20/12/2016 ; Aprovado: 26/Janeiro/2017. 
developmentalism, whereby the state coordinates the non-competitive sector of the economy and the five macroeconomic prices (which the market is unable to make "right"), while the market coordinates the competitive sector. In the 1970s, a crisis opened the way for a short-lived and reactionary form of capitalism, neoliberalism or rentier-financier capitalism. Since the 2008 Global Financial Crisis, the neoliberal hegemony has come to an end, and we are now experiencing a period of transition.

KEYWORDS: Capitalism; developmentalism; economic liberalism; rentier-financier capitalism. JEL Classification: P2; O1.

Capitalist societies will be either developmental or liberal depending on the way they deploy their major institutions, namely the state and the market. Economic liberalism gives full primacy to the market, while developmentalism combines state and market in a more balanced way. Developmentalism and economic liberalism are not only ways of coordinating capitalism but also ideologies, each ideological camp asserting the superiority of its form of capitalism. And developmentalism may be also a theoretical framework for understanding economic development as the outcome of moderate intervention by the state in the economy. The state, as the more encompassing and sovereign institution, has historical precedence over the market in coordinating society as a whole, and also in coordinating the capitalist economic system; but we should not disregard the fact that the market is an excellent institution provided that competition really exists. Capitalism originally took the form of mercantilism (the first manifestation of developmentalism) and was transformed into economic liberalism in the nineteenth century. Marx supposed it would change into socialism, but instead it was transformed into technobureaucratic capitalism after the Second Industrial Revolution, into social-developmental capitalism during the Golden Years of Capitalism, and from around 1980 once again into liberal capitalism. But whereas liberalism was originally the capitalism of business entrepreneurs, now it has become the capitalism of rentiers and financiers.

In this essay, I focus on the two forms of capitalism from the perspective of their dominant form of coordination: the state or the market. I acknowledge that I have an ideological bias, but my main argument is that developmentalism is a more balanced form of coordinating capitalism than economic liberalism, and generates more growth with financial stability. I would add that developmentalism better serves the goals of reducing inequality and protecting the environment, but that discussion is beyond the scope this paper.

In order to define the forms of capitalism, we need to know how the state and the market perform their coordinative role. The market is unbeatable in coordinating competitive systems, while the state is the overarching institution that coordinates modern societies. The state is the legal system and the sovereign organization that guarantees it. Thus, the state coordinates the whole society, while the market, 
duly regulated by the state, coordinates the competitive sector of the economy. The form that capitalist societies assume in any historical moment will depend on whether the state or the market prevails. In this paper, my objective is to understand developmental capitalism and the developmental state. Social and political theory does not offer an alternative concept to liberal capitalism. Socialism, which often purports to play this role, is actually an alternative to capitalism. In proposing developmentalism as the alternative to liberal capitalism, I hope to fill a gap in our thinking. Another possibility is the so-called "mixed economy", but this refers to a mix of socialism and capitalism. Developmentalism is not that. It is not a transition to socialism, but is a way of making capitalism more efficient and also, when it is progressive or social democratic, less unjust.

In claiming this meaning for developmentalism (a form of capitalism), I am doing a semantic widening. I am adopting a broad concept of developmental capitalism because it encompasses all economic systems that combine moderate but effective state intervention in production and in the distribution of income. My methodological approach in this semantic widening is to combine ideal-type definitions of developmentalism and economic liberalism with the historical method whereby the identification of new historical facts is crucial to understand society and the economy. "Developmentalism" is a relatively recent expression, used in Brazil since the 1960s. Chalmers Johnson (1982) is often cited the academic who originally defined the developmental state in his remarkable book on Japan and, specifically, the Ministry of the Economy, Trade and Industry (MITI); but, as Pedro Cezar Dutra Fonseca (2015) has shown, the concept of developmentalism was already being used in Brazil in the 1960s, in the works of Hélio Jaguaribe and BresserPereira. In the 1980s the expression "developmental state" gained a wider currency. Developmentalism is also a theoretical framework. Between the 1940s and the 1960s, development economics or classical developmentalism inaugurated the systematic study of development and underdevelopment, which was named "development economics" or "classical developmentalism". It originated in the classical political economy school, development economics, post-Keynesian macroeconomics, and the French Regulation School..$^{2}$ Since the early 2000s, a group of economists, principally in Brazil and Argentina, have been involved in constructing a new theoretical framework - "new developmentalism" - of which this paper is a summary.

\footnotetext{
${ }^{1}$ For a discussion of concepts and of semantic widening, see Fonseca (2015), who quotes Giovanni Sartori (1970) on the subject.

${ }^{2}$ There is a growing literature on new developmentalism. Here, I cite two books: Bresser-Pereira (2010a) and Bresser-Pereira, Oreiro and Marconi (2014).
} 


\section{THE GENERAL ARGUMENT}

In analyzing the forms of capitalism and of the state, we must, first, ask how, historically, capitalist societies have been coordinated, that is, which are the institutions or rules that preside over social action, which rights are assured and which obligations individuals have to the nation, how political objectives are set, how productive factors are allocated, how wealth and income are distributed, and how global warming is avoided. Second, we must know how strong or commanding are such coordinating institutions, or, in other words, how cohesive is the nation-state - the political-territorial society appropriate to capitalism - a role performed by empires in ancient societies. The more cohesive the nation is, the higher will be the degree of compliance by its citizens with the values and beliefs around which the nation is organized, the more legitimate and capable will be its state, and, so, the lower the level of coercion that will need to be used. The social cohesiveness of a nation depends on how much its citizens

- share a common history and common interests;

- agree on the political objectives that have become relatively consensual in modern societies (social order, freedom, material well-being, social justice and protection of the environment) and the individual obligations involved;

- see the nation as the source of solidarity, not only in competition with other nations but also internally, notwithstanding the inevitable conflicts associated with inequalities of income and wealth and of power and prestige associated with social class, gender, and race;

- are able to make compromises among themselves, that is, to engage in politics, without which a common life is impossible.

To the extent that a society is relatively cohesive, or, as Durkheim put it, is organic, the state will be legitimate and competent. We can compare developmental capitalism and liberal capitalism in terms of this criterion. Economic liberalism is characterized by pervasive competition, inequality and radical individualism, which means that it generates a low level of social cohesiveness. Developmentalism limits competition and emphasizes national solidarity, and may be conservative or progressive. Conservative developmentalism is less damaging to social cohesiveness and less concerned with inequality than is progressive developmentalism, and this facilitates a developmental class coalition embracing both the workers and the industrial entrepreneurs.

In this paper, I discuss developmental capitalism and liberal capitalism as two forms of the economic and political coordination of capitalism and its transformation. I don't discuss the models or varieties of capitalism which compare synchronically different models in different countries; rather, I seek to understand the historical phases of capitalism as defined in developmental versus liberal terms. I ask why capitalism was developmental in its original mercantilist phase, turned liberal in the nineteenth century, reverted to being developmental and social democratic 
after 1929, became neoliberal around 1980, and has been in crisis since 2008. My general argument is that the state and the market - the two core institutions of capitalism - play key roles in the coordination or regulation of modern or capitalist societies, but the state is the fundamental or default institution while the market is the institution that coordinates the competitive sector of the economy. My second argument is that developmentalism is superior to economic liberalism because it relies on the state and the market in a more balanced way and achieves better results.

Whenever there is effective competition, the market is the better alternative because it allocates resources automatically and more efficiently. The state is supposed to coordinate the non-competitive sector, the five macroeconomic prices (the profit rate, the interest rate, the wage rate, the inflation rate and the exchange rate), the distribution of income, and the protection of the environment - four areas where there is no real competition and so the market is not a viable alternative. If as well as developmental the state is social democratic (it may be conservative), it will limit the capacity of the rich (and also of the more educated) to cross Michael Walzer's (1983) "spheres of justice" and to enjoy better access to good-quality education and health care. The social-democratic state has no objection to capitalists using their money to buy luxury goods and services, but seeks to neutralize their capacity to buy prestige, political power and privilege.

After the Great Depression and Word War II, Western Europe adopted a socially progressive form of developmentalism, while liberal capitalism remained dominant in the United States. In Europe, social democracy and Keynesian macroeconomic policy reduced inequality, provided universal health care, and offered palpably better working conditions to workers than those prevailing in the United States. Yet, profits were squeezed by the increasing power of the unions, the ensuing economic crisis in the 1970s, the emergence of stagflation in rich countries, and the new competition in manufactured goods exported by the low-wage developing countries. These four factors precipitated a crisis in Keynesian macroeconomics and classical developmentalism. They were eclipsed by neoclassical economics and neoliberalism, which criticized the developmental state and social democracy, and defined as its major objective reducing wage and non-wage labor costs in response to the new competition. With this objective in mind, neoliberal economists insisted that liberal capitalism was superior to social democracy and developmentalism, arguing that markets are more "impersonal" in coordinating the economy, while ceasing to protect workers would encourage work and punish laziness. But they were unable to demonstrate such superiority, essentially because the greater social cohesiveness of the European societies compensated for the extra costs embedded in the welfare state and in the protected labor market. But the fact remains that the political center of the policy regime moved to the right in the late 1970s, as Przeworski (2001) and Bresser-Pereira (2001) have argued. In the 1990s, Anthony Giddens (1998) proposed the Third Way - a compromise between economic liberalism and progressive developmentalism - which was strongly criticized by the left, but reflected the turn of social democracy to the right. More recently, from 2008 the center moved again, now 
most likely toward a conservative developmentalism, but this change is beyond the scope of this paper.

\section{INSTITUTIONS AND THE BASIC HISTORICAL STAGES}

To understand capitalism, we must consider its basic institutions; how they regulate the division of labor; how factors of production are allocated; how rights and obligations are shared; how common goals are set; how wealth and power are distributed; how the class struggle is resolved; how cross-class coalitions are formed; how institutions become more cohesive and form a nation; and how they are open to social innovation. The elements involved in the social coordination process make clear the fundamental role that coordination plays in putting together and strengthening any given society. In light of this, we can divide the history of mankind in three major stages: primitive community, slave or ancient society, and capitalist society (Table 1). This macro periodization is often cited, and it becomes clearer if we consider the two main institutions in each phase. In primitive societies, tradition and religion were the two main institutions coordinating society; in slave societies, or in the ancient empires, religion again and the ancient state performed this role; and, in capitalist societies, the modern state and markets are the main coordinative institutions. Thus, the secondary institution in each phase becomes the primary institution in the following phase.

The ancient state was essentially an instrument of the military and land-owning oligarchy devoted to war for the purpose of conquest and colonization, or in order to plunder and to reduce the dispossessed to slavery. Together with religion, it coordinated and legitimized the power of the governing oligarchy. With capitalism, the state turns national, acquires a rational or bureaucratic structure, and shares the coordinating role with a new institution: the national market. The constitutional and rational state that Locke championed and Hegel first understood in its historical dimension is the state that originally promoted the interests of the monarch and its aristocracy. It is the state of the long transition from ancient to modern societies; it is a state that gradually became liberal, responding principally to the interests of the bourgeoisie. Finally, at the beginning to the twentieth century it turned democratic, opening itself to the three social classes that define modern capitalism: the bourgeoisie, the technobureaucracy, and the working class. In consequence, besides guaranteeing the profit rate, which is essential for the reproduction of capital, and the high salaries that are required to pay the professional or technobureaucratic class, the modern state today also represents to some extent the popular classes - which explains why economic elites have become so bitterly critical of the democratic state.

The market, in its turn, is the national institution regulated by the state that performs its coordinating role through economic competition. And soon an international market also emerges. Since capitalism was the first basic form of society or mode of production to be coordinated by markets, it is often called "market 
society". Before capitalism, markets were rather local fairs, and played a marginal role in economic and even social coordination, not only because they lacked the means but also because religion, tightly linked to the state, did this job. Under capitalism, the market assumed a new and major role. As Marx well noted, capitalism is the mode of production where money and the market are the core economic institutions; it is the society defined by the process of commodification (the transformation of everything into commodities, beginning with the labor force) together with the process of capital accumulation.

Table 1: Historical stages and respective coordination

\begin{tabular}{|c|c|c|}
\hline Historical stages & Political-territorial societies & Forms of coordinating institutions \\
\hline Primitive & Tribes & Tradition - Religion \\
\hline Slave & Classical empires & Religion - State \\
\hline Capitalist & Nation-states & State - Market \\
\hline
\end{tabular}

Table 1 shows the four basic institutions, the three stages (primitive, slave and capitalist), and the corresponding forms of political-territorial society:

- the tribe is the loose territorial society of primitive societies;

- the empire is the ever-expanding or narrowing political-territorial society where slaves produce while the military aristocracy takes charge of wars, religion, administration, and colonies;

- the nation-state is the political-territorial society specific of capitalism.

The nation-state is the sovereign political-territorial society formed out of a nation, a state and a territory. Since formal colonies disappeared after World War II, nation-states cover the entire globe. Following Ernest Gellner (1983), in the ancient empires the state regulated only the core of the imperial system; the rulers were not interested in transferring its superior culture to the colonies, which were expected just to pay taxes, not to integrate with the center. The last representatives of the classical empires - the Austro-Hungarian Empire and the Ottoman Empire - did not seek to integrate the colonies into their superior culture, but only to force them to pay taxes. Completely different are the capitalist nation-states, in which the state corresponds to a nation, which, domestically, is supposed to be integrated and relatively solidary, having as its main objectives national security and economic growth. For Gellner (1983, p. 32) the industrial society "is, ultimately, a society based on economic growth...", a society in which there is "the hope of perpetual increase of satisfactions and whose legitimacy depends on their ability to meet this expectancy". This means that the superior culture existing at the core of such nation-state is supposed to be spread to the whole society, which thus shares the common basic knowledge required for ever-increasing productivity. Whereas in pre-capitalist societies the concept and the objective of economic development 
was absent, in capitalist societies it becomes a major goal of the state, as profit becomes the crucial motivation of business enterprises, to be achieved by investment that incorporates technical progress.

Both the mercantilist and the classical political economists knew that their discipline had become possible only when markets assumed the role of coordinating modern national societies, but they also knew that markets don't exist without the state, and are unable to coordinate all economic activities. For that reason, they called the new science they were founding "political economy". The capitalist class also understood the importance of both the state and the market in the economic coordination of modern societies, and for that reason combined economic nationalism or developmentalism with economic liberalism. Neoclassical economists lost view of this simple truth. Fascinated by the power of the new coordinating institution based on competition, which is apparently a self-regulating form of social coordination, independent of the will and the say of governments, the economists of the neoclassical and also the Austrian schools of thought transformed the market into a kind of myth, and attributed to it a role that is far beyond its capacities. The state and the market are the main institutions coordinating capitalism, but the coordinating role of the state is broader because the state comprises not only the government or the public administration (the state organization) but also the legal system. The state is the overarching institution endowed with sovereignty, while the market is an institution regulated by the state that is able to coordinate the competitive sectors of the economy. This means that a large non-competitive sector, consisting principally of infrastructure and the industry that manufactures basic inputs, is excluded from market coordination. As for the macroeconomic domain, it has been definitively established that markets are unable to get the five macroeconomic prices right, and so the developmental state is supposed to adopt an active macroeconomic policy, particularly in relation to the exchange rate and the corresponding current account in order to keep national economies on the road to financial stability and growth.

\section{ECONOMIC AND POLITICAL LIBERALISM}

Economic liberalism should not be confused with political liberalism, which in the eighteenth century contributed to the affirmation of civil rights. Yet political liberalism is also problematic. It long opposed democracy, and its concept of freedom is quite different from the republican concept of liberty. For liberals, liberty is the "liberty of the moderns" - men are free just when they may do whatever they want if is not against the law. In contrast, the republican concept of freedom maintains that citizens are free if and only if they defend the public interest even when it conflicts with their personal interests. ${ }^{3}$ When political liberalism is freed from the moral cri-

\footnotetext{
${ }^{3}$ This discussion was born with Benjamin Constant (1814) - a liberal who favored the liberty of the
} 
tique of republicanism, it loses the ideas of national solidarity and public interest, and degenerates into radical individualism. Britain completed its capitalist revolution around 1800, and turned democratic around 1900, protecting not only civil rights but also universal suffrage. It thus took one hundred years for liberals stop fearing and opposing democracy with the argument that it meant "the tyranny of the majority". Today, in the more advanced countries, the economic elites accept democracy but fear it, and are to an extent republican when they cease to be liberal.

Liberal ideologues oppose liberalism to socialism, and conclude that only liberalism is consistent with democracy. Actually, in the first three-quarters of the twentieth century several developmental countries underwent their industrial revolutions, and then made their transition to democracy; in the twenty-first century, the challenge they face is to combine growth with reducing inequality and protecting the environment. Developing countries were developmental when they experienced their industrial revolutions; when they became democratic they did so directly, while rich countries, which also industrialized under authoritarian regimes, were liberal for around a century before turning democratic. Developmentalism is more compatible with democracy than is economic liberalism because, although the public interest and the interests of the popular classes are not the same, they are not as divergent as are the public interest and the interests of the capitalist class - the latter being today, chiefly, the interests of its ever-increasing rentier segment. What is not consistent with democracy is statism - the state assuming the full coordination of the economy. When Friedrich Hayek, in his book The Road to Serfdom (1944), opposed liberal capitalism to socialism, socialism was still viewed as a possible short-term alternative to capitalism. After the Budapest uprising of 1956 and the Prague revolt of 1968, it became clear that the Soviet Union was not a socialist but a statist society. At that time, it seemed that statism was effective in promoting growth and, so, posed a challenge to capitalism. After the war, the Soviet Union experienced accelerated growth, and Nikolai Khrushchev predicted that in twenty years the Soviet economy would surpass the North American. Yet from the early 1970s the Soviet economy stagnated, showing that statism could be effective in achieving primitive accumulation and promoting heavy industrialization but incapable of efficiently coordinating complex economic systems.

Historically the role of markets in coordinating capitalist societies has been overestimated, for several reasons. First, capitalism was the first mode of production in which a national market became one of the two main coordinating institutions. Second, economics is essentially a science of how markets coordinate economic systems. Third, the challenge of devising a theory in which the market fully and satisfactorily coordinates the economy is very attractive to academic economists. After neoclassical economics turned mainstream in the late nineteenth century, replacing classical political economy, economists adopted the hypothet-

moderns against the liberty of ancients. In the twentieth century, Isaiah Berlin (1958) revived these ideas, while Charles Taylor (1995) advanced the classical republican critique of liberalism. 
ic-deductive method build mathematical models that reduced their science to a system of equations. From this moment on, economic theory changed from "political economy" to "economics", and neoclassical economists became involved in the "scientific" project of building a supposedly non-historical and non-ideological science.

Neoclassical and also Austrian economists found a receptive audience among the bourgeoisie, which was always attracted to liberalism but never ceased to be also nationalist. Nationalist in economic terms, and so developmental, because business entrepreneurs always viewed the domestic market as their main asset, and the state as its instrument to guarantee their monopoly over this market and to negotiate their access to other countries. Thus, developmentalism has always been present in coordinating capitalism, dialectically associated in some form with economic liberalism: first, in the central countries that originally industrialized, like Britain and France, in the framework of mercantilist capitalism; second, in the central latecomer countries like Germany and the United States in the nineteenth century; third, in the peripheral independent countries of East Asia; fourth, in the peripheral national-dependent countries of Latin America; and fifth, again in the original central countries, in the framework of the New Deal plus the post-war Golden Years of Capitalism (or of Fordism) - a time when developmentalism and social democracy coincided. ${ }^{4}$ Economic liberalism was dominant in the original countries between the 1830s and the 1920s, and from the 1980s - this second time in the form of a reactionary rentier-financier capitalism.

\section{DEFINING THE DEVELOPMENTAL STATE}

Nations build their state and their nation-state, the latter the sovereign territorial political society formed out of a nation, a state and a territory. Such a social construction soon assumes a formal character - the building of the legal system which is not exogenous, as the new institutionalism (associated with neoclassical economics) assumes, but endogenous. In fact, institutions are not the fruit of purely rational choices, but are the outcome of a complex historical process that relates the economic infrastructure with institutional and cultural instances, and of political strategies and compromises, of class struggle and class coalitions. In this social construction, capitalist society and the modern state are so deeply intertwined that when we refer to the liberal state we are also referring to liberal capitalism, and when we refer to the developmental state we are referring to developmental capitalism.

In modern societies, the degrees of state intervention may be thought as disposed along a continuum running from liberal capitalism to statism, with develop-

\footnotetext{
${ }^{4}$ It is important to note that developmentalism may be conservative or progressive, whereas social democracy is, by definition, a center-left political orientation.
} 
mentalism in the middle. Capitalism is liberal when it is coordinated almost exclusively by the market; it is developmental when it combines state and market coordination. When coordination is almost exclusively undertaken by the state, we have a statist or purely technobureaucratic society. I have already defined developmentalism and economic liberalism, but let me elaborate these definitions. A given capitalist society the state will be developmental if

- the society makes economic development its priority, and industrialization or productive sophistication the means to achieve it;

- the market coordinates the competitive sectors of the economy, the state being engaged only in strategic and temporary industrial policy;

- the state coordinates closely the non-competitive sector of the economy (infrastructure, basic industries, and major financial institutions), and

- the state is responsible in fiscal as well in exchange rate terms, not incurring chronic budget and current account deficits;

- the state assumes a proactive role in keeping the five macroeconomic prices balanced (the profit rate, the interest rate, the wage rate, the inflation rate and the exchange rate), particularly the last of these.

This nation-state will be additionally progressive if it

- is engaged in reducing economic inequality, and

- actively protects the environment.

A capitalist society will be liberal if the state limits itself to guaranteeing property rights and contracts, and to balancing its fiscal accounts, while the market takes care of the rest - of growth and economic stability. Developmentalism presupposes that economic development is the outcome of political design, where markets have a major role, but the will of citizens is the crucial variable; economic liberalism sees development as the outcome of exogenous institutions defined by the economic elites and international agencies designed to defend economic liberalism and rentier-financier interests.

This concept of developmental capitalism and the developmental state is broader than that adopted by Chalmers Johnson $(1982,1999)$, who took Japan as his model. Johnson defined the developmental state as a state whose primary objective is economic development; that is between laissez-faire and state socialism; that intervenes in the economy not just in a regulatory way but also in a "substantive" way through an active industrial policy; that implies a small and highly qualified public bureaucracy to which are ascribed effective powers, leaving the legislature and the judiciary in the background; that controls the external financial accounts, and therefore the exchange rate; that protects domestic manufacturing industry; that facilitates the import of machinery; that distinguishes foreign technology, in which it is very interested, from foreign capital in which the country is interested; which creates public financial institutions; which provides intense but always tem- 
porary credit incentives and tax reductions that depend on constant evaluation; which adopts a consolidated budget of public investment; that offers strong government support for science and technology; that rejects detailed regulations and creates space for the initiatives of companies and the discretionary guidance of the public bureaucracy. The definition I am proposing is similar to Johnson's. It is neither normative nor a generalization from Japan's growth strategy, but a generalization from the behavior of developmental states, especially the countries of eastern Asia and Brazil at the time of industrialization. The definition of the developmental state in South Korea is also quite similar. For Johnson, the basic features of South Korea's successful catching up were twofold: (a) microeconomic policies: industrial policy (high import tariffs in the 1970s, ranging between $30 \%$ and $40 \%$, and in the 1980s between $20 \%$ and 30\%; many non-tariff barriers; and large export subsidies; and (b) macroeconomic policies: small fiscal deficits; a low public debt to GDP ratio; heavily regulated financial markets; low interest rates, often negative; strict control of the exchange rate; strict control of inputs and capital outflows; and low inflation. ${ }^{5}$

My concept of developmental state and developmental capitalism is originated in the political economy of classical developmentalism, whose pioneer was Mihail Manoilescu (1929) and a key author, Hélio Jaguaribe (1962), on the post World War II literature on the social-democratic and the corporatist state already referred, and on the literature of modern state and bureaucratic state, from which Peter Evans (1992) is the main representative. Evans emphasizes bureaucratic capacity and "embedded autonomy" - the insertion of public bureaucracy in the society and in the business community, acting with relative autonomy in relation to the dominant class - as essential characteristics of the developmental state.

The role of the state in capitalist societies is to maintain the general conditions of accumulation. Classically, these are education, institutions that guarantee property right and contracts, investment in infrastructure and the availability of credit. Keynesian macroeconomics added a fifth condition - the existence of aggregate demand - and new developmentalism a sixth general condition: keeping the five macroeconomic prices right, particularly the exchange rate, which, when it is overvalued over the long term, threatens competent companies' access to domestic and foreign demand. Just as Keynes showed that monetary economies face a tendency to the insufficiency of demand, new developmentalism argues that developing countries face a tendency to the cyclical and chronic overvaluation of the exchange rate. As the experience of the East Asian countries has demonstrated, keeping the budget deficit as well as the current account under control is a necessary condition for keeping the macroeconomic prices right and the macroeconomic aggregates balanced. The widespread idea that associates developmentalism with financial prof-

\footnotetext{
${ }^{5}$ I took these characteristics from the classes that Chang offers yearly in Brazil in Laporde - Latin American Advanced Programme on Rethinking Macro and Development Economics.
} 
ligacy is just vulgar Keynesianism or fiscal populism. Expansionary fiscal policies are required countercyclically, not chronically.

\section{DEVELOPMENTAL CLASS COALITION}

The developmental state requires a proactive administration and a developmental class coalition to support it. Industrial entrepreneurs, workers, public bureaucrats, and sectors of the old oligarchy originally formed the developmental class coalitions that presided over the formation of the nation-state in each country. In pre-industrial countries, sectors of the old commodity-producing ruling class and business importers and exporters formed the liberal-conservative class coalition; today, rentiers, financiers, the top executives of corporations, the traditional middle class and foreign interests usually form the liberal-conservative coalitions in peripheral countries. Chalmers Johnson and Peter Evans attribute to public bureaucracy a strategic role in the developmental state, which is correct, but industrial entrepreneurs play the decisive role, first, because their separation from the rentier capitalists is a condition for this coalition, and, second, because they exercise a veto power as they decide whether or not to invest.

Developmental class coalitions are always changing. The most recent developmental class coalition in rich countries, Fordism, was a broad coalition embracing industrial businessmen, entrepreneurs and executives associated with the new information technologies, the public technobureaucracy, the non-rentier sectors of the middle classes, and the workers. The opposing class coalition - the neoliberal coalition - is a narrow rentier-financier alliance of top and middle-class rentiers, financiers, and top executives of business corporations, ${ }^{6}$ whose income consists of rentiers' rents and dividends and financiers' high salaries, commissions and bonuses. While business entrepreneurs are essentially interested in profit, the liberal coalition gives priority to interest and dividends, not profit, ${ }^{7}$ and to low inflation, not economic growth. In other words, the logic of rentier-financier capitalism is short-term shareholder value maximization, not the classical capitalist or business entrepreneurs' logic of long-term profit maximization and growth. The narrowness of the rentier-financier coalition conflicts not only with the interests of the workers and the poor, but also with the interests technobureaucratic or professional middle class. Only the interests of the top executives of the great corporations coincide with the interests of the shareholders or rentier capitalists. Shareholders are ready

\footnotetext{
${ }^{6}$ Rentier capitalists are the "unproductive" capitalists to whom Marx refers in volume 3 of Capital. They live on interest, dividends and rents. Besides the wealthy rentiers, there is a large number of middle class rentiers. Rentier capitalists play today the role that rentier aristocrats played in David Ricardo's political economy. It is for that reason that Keynes spoke about "the euthanasia of the rentiers".

${ }^{7}$ Which is possible when, for instance, business enterprises, under pressure from shareholders and the financial system, are "short termist" and distribute profits in the form of dividends when it would be rational to invest and realize higher profits.
} 
to award absurdly high salaries and stock options to top executives, because a competent management makes a major difference to the returns on investment and, so, to the market value of individual corporations.

The two class coalitions are loose and fluid. When the capitalist class feels threatened by left-wing political parties, it tends to rally. In normal conditions its conflicting interests overcome shared ones, and the ruling class is divided: the local rentier-financier coalition remains loyal to economic liberalism and, so, dependent or colonial in relation to the central countries or the West, while the business entrepreneurs' coalition is nationalist and adopts some form of developmentalism. Often it is difficult to distinguish the entrepreneurial capitalists from the rentier capitalists, but such a distinction, although relative, is essential to explaining capitalist societies. Considering the citizens of a nation-state, between the two coalitions there is a changing and undefined "middle", which is populated by those who have little interest in politics and little power in civil society.

The relationship between agrarian elites and developmental class coalitions is a complex one. In some cases, agrarian elites are members of such coalitions, in others they oppose them. As Marcus Ianoni notes (2014, p. 99), "in South Korea and Taiwan, the rural society converged with industrial progress, not seeking an independent political settlement". The same is true of the German agrarian elites, which Bismarck was able to attract into his developmental class coalition. In Brazil, the agrarian elites in the pre-industrial and the industrial revolution phases opposed the developmental state. The different economic and social conditions of agricultural producers may explain their opposition. In countries like Germany and South Korea, agriculture exists essentially to supply the domestic market, while in Brazil, during the period of the industrial revolution (from the 1930s to the 1970s) the main agricultural products were commodities for export. Given that such commodities triggered the Dutch disease (they could be exported at a profit with a substantially higher exchange rate than the one required by competent manufacturing companies), and given that the way to neutralize such economic disadvantage is to impose a variable tax on such commodities (or to impose high import tariffs and to subsidize exports of manufactured goods), the big farmers opposed industrialization. Growth in Brazil was extraordinarily successful between 1930 and 1980, because the developmental state was able to neutralize the Dutch disease through a disguised export tax which farmers hated, calling it "exchange confiscation". Yet, between 1930 and 1950, the support of that sector of the agrarian oligarchy that was oriented to the domestic market and not involved in exporting commodities was fundamental to the success of the national-popular pact that Getúlio Vargas led.

The long transition from pre-industrial to industrial society lasted centuries in the countries that industrialized first - England, France and Belgium. It had the industrial revolution as its concluding and crucial moment, after the formation of the nation-state. In each country, the respective industrial revolutions have taken place in the framework of developmental capitalism, but the form of the developmental states changed, depending on whether the country was central or peripheral, and on the period of time in which the national and industrial revolutions 
happened. An overview of all the countries that industrialized and became rich or middle-income capitalist countries shows that the industrial revolutions were: (a) mercantilist in the central countries that first industrialized, such as England and France; (b) Hamiltonian or Bismarckian in latecomer central countries, which were not colonies but which were late in carrying out their industrial revolutions, such as Germany and the United States; (c) independent in colonies or quasi-colonies of central countries that achieved a high degree of national autonomy, industrialized and caught up, as was the case with Japan, Taiwan and South Korea, or are still catching up, as are China, India and Indonesia; and (d) national-dependent in Brazil and in Mexico, which achieved a certain national autonomy and managed to undertake their industrial revolutions between the 1930s and the 1970s, thus catching up, but which after the major foreign debt crisis of the 1980s lost national autonomy, adopted a liberal economic policy regime, ceased to be developmental states, and from then on grew slowly. ${ }^{8}$

The adoption of a developmental format or a developmental policy regime provides no guarantee that the state will perform its role adequately. The developmental state presupposes competent and republican (i.e., public-spirited) elected and non-elected officials. Considering the developing countries, Peter Evans (1992, p. 12) remarked that, besides the developmental and the liberal states, there is the "predator state", which "has no ability to prevent its leaders pursuing their own goals; personal relationships are the only source of cohesion, and the maximization of the interests of individuals takes precedence over the common goal". Predator states exist in preindustrial countries that have not yet undergone their industrial and capitalist revolutions. Their leaders say they are either liberal or developmental, according to the convenience of the moment, but this means little or nothing. In theory, they can become developmental states or liberal states, but if they opt for the first alternative, the likelihood is that they will develop and achieve very little in the way of catching up; if they choose the second alternative, they may succeed in industrializing or in increasing productive sophistication, but this is no more than a possibility.

Between developmental capitalism and liberal capitalism there is a grey area. There are moments when it is difficult to determine the character of capitalist systems, because the governments in some countries have turned liberal but the state continues to intervene in the economy. In the Neoliberal Years of Capitalism, capitalism didn't become objectively liberal in the European countries, but neoliberalism became the dominant ideology and politicians followed neoliberal policies. The consequence was the 2008 Global Financial Crisis and the 2010 Euro Crisis. Behind the two forms of capitalism and the two forms of state there are the respective schools of economics that legitimize them and influence economic policy - which is not surprising, given that economics is a highly ideological social science. Behind the developmental state are development economics or classical developmentalism,

\footnotetext{
${ }^{8}$ See Bresser-Pereira (2016).
} 
post-Keynesian macroeconomics, modern Marxism, neo-Schumpeterian microeconomics, the French Regulation School, and new developmentalism, which comprises a macroeconomics and a political economy (to which this paper belongs). Behind liberal capitalism and the liberal state are neoclassical economics and the Austrian school of economics.

\section{TWO FORMS OF CAPITALISM}

The fact that the developmental state is at the core of the history of capitalism is not the result not of chance but of its basic orientation to economic growth. On the other hand, capitalism is founded on economic competition in the marketplace, which is associated with economic liberalism, but to be effective it depends on the existence of cooperation and a reasonable cohesiveness, which only the nation and a developmental and progressive coalition may achieve. Under capitalism, collective action tends to be feeble because domestic competition has precedence over cooperation; but economic nationalism is a major source of social cooperation not only in the international realm, where global competition requires national solidarity, but also in the domestic realm.

In the "original countries", England and France, we have two forms of capitalism, according to the degree of state intervention or active economic policymaking: developmental capitalism and liberal capitalism. Within developmental capitalism we have two phases (mercantilist and Golden Years capitalism), and within liberal capitalism also two phases: industrial capitalism and rentier-financier capitalism. Table 2 shows these two forms, four phases, alternative names for them, and approximate periods.

Table 2: Two forms and historical phases of capitalism (with reference to United Kingdom and France)

\begin{tabular}{|c|c|l|}
\hline Forms & Period & \multicolumn{1}{c|}{ Phases } \\
\hline \multirow{4}{*}{$\begin{array}{c}\text { Developmental } \\
\text { Capitalism }\end{array}$} & $16^{\text {th }}$ to $18^{\text {th }}$ C. & Mercantilist Capitalism (1 ${ }^{\text {st }}$ developmentalism) \\
\cline { 2 - 3 } & $1940-1979$ & Golden Years of Capitalism (2 ${ }^{\text {nd }}$ developmentalism) \\
\cline { 2 - 3 } & $(1929-1940)$ & (Great Depression) \\
\hline \multirow{2}{*}{$\begin{array}{c}\text { Liberal } \\
\text { Capitalism }\end{array}$} & $1834-1929$ & Industrial Capitalism \\
\cline { 2 - 3 } & $1979-2008$ & Rentier-financier Capitalism \\
\cline { 2 - 3 } & $(2008-.)$. & (Crisis) \\
\hline
\end{tabular}

Mercantilist capitalism, encompassing the sixteenth, the seventeenth and the eighteenth centuries, was the phase of transition from feudalism to capitalism, the era of the absolute state, of the primitive accumulation of capital, of the formation of the first nation-states, and, finally, it was the moment of the Industrial Revolution 
in England - the economic revolution which definitively gave rise to capitalism or modernity. It was the moment of the configuration of what Immanuel Wallerstein (1980) called "the world system". Mercantilism was the era of the first developmental capitalism in so far as it was based on a developmental class coalition formed by the monarch, the aristocrats around him, and the emerging great commercial bourgeoisie. Per Amiya Kumar Bagchi (2000, p. 399), "the first developmental state to emerge since the sixteenth century was that of the northern part of the Spanish Netherlands, which, after the re-conquest of the southern part by Spain, evolved into today's Netherlands". The mercantile bourgeoisie originally derived their wealth from the long-distance trade of luxury goods, but, with the rise of manufacture, they soon became interested in the formation of a secure and large domestic market, which would make possible the mass production of the cheap industrial goods that defined the Industrial Revolution. With this medium-term objective in mind, while reaping short-term gains from the mercantilist monopolies awarded by the monarch, they financed the wars initiated by the monarch - wars that defined the territorial space of the first nation-states and opened the way for the Industrial Revolution. Was Mercantilist Capitalism as bad as liberal economists claimed it was? Definitely not. To have been the moment of the Industrial Revolution proves that it was enormously successful.

In 1834, when the United Kingdom finally reduced its high import duties, we may say that we arrive at liberal and industrial capitalism. We may also call it business entrepreneurs' capitalism, because it was led by Schumpeterian entrepreneurs. Industrial capitalism was liberal in economic terms because the state had no direct role in production, and in political terms because the new ruling class secured civil rights (but not political or social rights). But it did not become a fully liberal state, because the state continued to be involved in the economy in many ways. As Pierre Rosanvallon (2011) remarks, at the end of the nineteenth century the fragility of the liberal state caused a revival of the ideas favoring greater intervention of the state in the economy. Yet state intervention was sufficiently limited in the original countries which industrialized that is reasonable to say that economic liberalism was dominant. Industrial capitalism was characterized by massive urban poverty and social dislocation, which gave rise to the deliberate reaction of the popular classes asking for socialism and democracy. They didn't achieve socialism, but won the battle for democracy at the turn of the twentieth century, when rich countries in which civil rights were already secured adopted the universal suffrage.

Industrial capitalism also emerged during the era of modern imperialism, which was led by the United Kingdom and France in the nineteenth century. ${ }^{9}$ The Industrial Revolution made these two countries sufficiently powerful in economic

\footnotetext{
9 This long period (1830-1929) may be divided in two (before and after the 1870s) because it was around that decade that wages in England and France ceased to be at the subsistence level and began to increase with productivity. It is also after the 1870 s that the European countries and the US became sufficiently strong to impose their colonial rule. I do not stress the distinction between the two periods in this essay, because it is not necessary for the argument that I am developing.
} 
and military terms to reduce the Asian and African peoples to the condition of colonial subjects - something that could not be done in the mercantilist period, when the local empires were sufficiently strong to resist colonization. As for the Latin American countries, at the beginning of the nineteenth century they had won independence from Spain and Portugal, and imperialism was defined in terms of ideological hegemony or soft power, first under the leadership of Britain, and after World War I, of the United States. Modern soft power imperialism is essentially characterized by the occupation of local markets by unequal trade, by finance, and by multinational corporations based on the cultural and political dependency of local elites. ${ }^{10}$ In the nineteenth century, in Asia, such occupation required war; in the twentieth century, the West submitted the local political and economic elites to their liberal "truth", although they did not adopt the recommended policies when they were themselves experiencing the corresponding phase of development.

Industrial capitalism has undergone a major change since the end of the nineteenth century in the form of the Second Industrial Revolution, which opened the way for the large corporations. From around 1890 to 1929 we have a transition phase, which was mainly defined by the Organizational Revolution - the moment when the units of production ceased to be based on the family and became private bureaucratic organizations or modern business enterprises, while the ownership and the management of business enterprises began to become separated. This change gave rise to a third social class in capitalist societies - the technobureaucratic class - and to the division of the capitalist class into business entrepreneurs and rentier capitalists. This was also the time of the Democratic Revolution - the transition of rich countries to democracy in so far as, at the turn of the twentieth century they assured the right to the universal suffrage. In the beginning of the twentieth century, many view industrial or liberal capitalism a definitive change, but, first, the 1914-1918 war, and second, a major economic crisis in the 1930s, the Great Depression, showed that this was an illusion, which has confirmed Karl Polanyi's (1944) claim that economic liberalism was a moment - and not a bright moment - in history.

After the 1929 crash and the Great Depression, Franklyn Delano Roosevelt's New Deal was the beginning of a major change in the history of capitalism. The period from the 1940s to the 1970s was the time of the Golden Years of Capitalism or Fordism, in which the people added the social rights to their civil and political rights: universal public education, universal health care, basic social security. This was the time of a second developmental capitalism, having as its guiding text John Maynard Keynes's General Theory (1936) and, as its key international monetary agreement, the Bretton Woods System. This was the moment when a broad developmental class coalition was formed comprising business entrepreneurs, the new technobureaucratic class, and the workers, which the French Regulation School called Fordism. This was the time of "indicative planning", the rise of state-owned

${ }^{10}$ Note that this cultural dependency proved to be much stronger in Latin America than in Asia. 
enterprises, high growth rates, financial stability, increases in the tax burden, the adoption of progressive taxation, and some reduction in inequality. These were the Golden Years of Capitalism, which Andrew Shonfield (1969), Jean Fourastié (1979), Michel Aglietta (1976) and Stephen Marglin (1990) were to examine. Or the years of corporatist capitalism, whose classical analysis was made by Philippe Schmitter (1974) having the North European countries as reference. This was the phase of capitalism in which all developed countries, on one side, adopted the welfare state by building the great and universal services providing health care, education, social security, and social assistance, financed by progressive tax systems, and, on the other side, augmented the labor entitlements in the capital-labor contracts that the companies had to pay directly to workers. ${ }^{11}$ This was the time of progressive developmentalism or Fordist class coalition; it was a period of fast growth, impressive financial stability, and a relative reduction of inequalities, in which the political center moved to the left, and the common political objective was to create a social or progressive capitalism, regardless of whether the political party in office was social democratic or conservative. In Germany, the conservative Christian Democratic Party proposed a "social market economy" which was essentially developmental and democratic. The Golden Years of Capitalism also amounted to a technobureaucrats' capitalism, because the leading professionals of the technobureaucratic class, which had been emerging since the Second Industrial Revolution, in this period joined the ruling class, in the public sector as well as in the public sector.

The Golden Years faced a political crisis with the 1968 student revolution, which marked not the beginning but the end of an era. In the late 1960s, the increasing power of the unions, and in the 1970s the North American repudiation of the last vestiges of the gold standard, the first OPEC oil shock in 1973, the stagflation in the United States, the rise of the newly industrializing countries (which since the early 1970s have been competing with rich countries in the export of manufactured goods), and the fall of the rate of profits - these six new historical facts were enough to dismantle the Fordist class coalition.

The rise of a second and radical economic liberalism - the Neoliberal Years of Capitalism - was a response to these facts. It was a rentier capitalism in which the rentier capitalists, the financiers that manage their wealth, and the top executives in the major corporations and in the state sector built a new and narrow liberal class coalition. Major liberal intellectuals, like Friedrich Hayek, Karl Popper, Milton Friedman and James Buchanan, played a strategic ideological role in converting the economic departments of the major universities to the abstract, hypothetico-deductive neoclassical models, whose role was to legitimize economic liberalism. The World Bank changed from a developmental to a neoliberal agency and took on a

\footnotetext{
11 These labor entitlements would be the main target of neoliberalism when it achieved hegemony and proposed reforms to make rich countries competitive in the face of competition from low-wage developing countries.
} 
new role: to impose liberal institutional reforms on developing countries. Although really existing socialism had turned purely statist and the Soviet Union, which was its model, collapsed in 1991, neoliberal rhetoric continued to ignore developmental capitalism and presented economic liberalism as the only alternative to statism.

The Neoliberal Years were also the time of financialization or of finance-led capitalism, as well analyzed by François Chesnais (1994), Michael Aglietta (1995), Robert Boyer (2000, 2004), Gerald Epstein (2005), and Robert Guttmann (2008, 2016). "Neoliberalism" is not an inaccurate term to describe the phenomenon, but I prefer "rentier-financier capitalism" because it conveys the essentially rentier character of neoliberal capitalism. Capitalist rentiers' new power stemmed from the huge accumulation of capital that has taken place in the world since the end of World War II. Before 1945, great wars and great financial crises extinguished excess capital. From this date, no longer. The world did not face major wars and great crises, and the profusion of capital in the hands of rentier capitalists made them powerful, while top technobureaucrats (of which financiers are a variety) replaced business entrepreneurs in the management of the great corporations. Rentier-financier capitalism represented "a historic shift in the preferred form of credit from loans to securities", which was the outcome of a series of financial innovations creating fictitious capital - "fictitious inasmuch as [it] had no counterpart in real physical asset values" (Robert Guttmann, 2008); or as "a distorted financial arrangement based on the creation of artificial financial wealth, that is, financial wealth disconnected from real wealth or from the production of goods and services" (Bresser-Pereira, 2010b).

At the beginning of the 1980s, neoliberalism achieved a hegemony in the US and in the United Kingdom, and soon spread to other countries at the same time as its tenets and reforms became "hegemony constraints" - constraints that are established when a given ideology (in this case neoliberalism) turns hegemonic and the corresponding policies and institutional reforms that are determined by the interests of the rentier capitalists and financiers come to be accepted by most as if they were real economic constraints - something that we have no alternative but to obey. ${ }^{12}$

Neoliberalism is often understood as a conservative ideology, but it is not, because conservatism is never radical, whereas neoliberalism soon became radical and reactionary. In order to increase the foreign competitiveness of a country and to reduce the tax burden, neoliberals are permanently involved in reforms which never end because the complexity of contemporary capitalism requires increased regulation by the state, and neoliberals don't recognize this structural constraint. The neoliberal project is a Sisyphean task, never to be completed. Neoliberal ideologues are always demanding new "reforms" that - they promise - will finally transform a given economy into the "ideal" free market economy. While conservatives criticized the utopian character of the left, neoliberals built their own utopia.

${ }^{12}$ See Bresser-Pereira (2014). 
Without realizing it, they have been offering nation-states and international institutions another example of tragedy repeating itself as farce.

Was economic liberalism - the general mode of regulation consistent with liberal capitalism - successful? Not very. Certainly, much less so than could be inferred or predicted after reading the harsh critical analyses of the mercantilist mode of state intervention by nineteenth century liberal political economists. Economic growth was marked by repeated financial crises and huge inequality, and was relatively slow: the UK and French average annual rate of per capita growth was $1.4 \%$, a substantially lower rate than these countries achieved in the twentieth century, in their second developmental experience - the 30 Golden Years of Capitalism (1946-1973 ) - when it reached $3 \% .{ }^{13}$ The first economic liberalism began in revolutionary mode, challenging the conservative ancien régime and defending civil liberties; but, as the bourgeoisie came to power, it gradually moved to the right - to preserving the liberal and authoritarian social order. A hundred years later it ended with the 1929 crash and the Great Depression.

Should we view neoliberalism as a second economic liberalism, as a durable form of capitalism? Probably not. It was rather a short-lived economic and political retrocession - a case of extreme individualism, where generalized competition unrestrained by solidarity creates permanent insecurity and increasing inequality, while oligopolistic market structures guarantee certain profits to the major private corporations, certain rents for rentiers, and high commissions and bonuses for financiers and top executives.

\section{CONCLUSION}

In summary, economic liberalism is not the "normal" or the "default" form of capitalism. Between developmental capitalism and liberal capitalism there is a grey area. There are moments when it is difficult to identify the character of capitalism, because in some countries governments have turned liberal but the state continues to intervene in the economy. In the Neoliberal Years of Capitalism, capitalism didn't turn objectively liberal in the European countries, but neoliberalism became the dominant ideology and politicians adopted neoliberal policies. The consequence was the 2008 Global Financial Crisis and the 2010 Euro Crisis. Capitalism was born developmental. I identified just two forms of coordinating capitalism, developmentalism and economic liberalism, and discerned four historical phases: mercantilist, liberal, Golden Years, and neoliberal, the first and the third developmental, the second and the fourth liberal.

Behind the two forms of capitalism and state there are the respective schools of

\footnotetext{
13 The average rates of annual per capita growth in France and the UK between 1830 and 1929 were, respectively, $1.6 \%$ and $1.2 \%$; between 1949 and 1978, $4.0 \%$ and $2.2 \%$. Source: Angus Maddison-OECD Growth and Development Centre statistics.
} 
economics that legitimize the respective ownership and power system. That a science justifies an ideology is not surprising, given that economics is a highly ideological social science. Behind developmental capitalism and the developmental state are classical developmentalism, post-Keynesian macroeconomics, modern Marxism, neoSchumpeterian microeconomics, the French Regulation School, and new developmentalism; behind liberal capitalism and the liberal state are neoclassical economics and the Austrian school of economics.

The Neoliberal Years of Capitalism were short-lived: neoliberalism collapsed economically in the 2008 Global Financial Crisis, and faced political crisis in 2016 with Brexit and the election of Donald Trump to the presidency of the United States. Neoliberalism was a radical and regressive moment in the history of capitalism which can hardly be viewed as a new stage of capitalist development. In this period, a reactionary and narrow class coalition concentrated power, income and privilege: the famous richest $1 \%$ of the people. It was a time of high financial instability, huge increase of inequality, and democratic decay for rich countries, principally for the US; a time when the rule of law discourse was intensified while civil rights were often ignored; when, besides the working class, the technobureaucratic class and the state bureaucracy were under attack; when regulatory agencies, including central banks, became "independent" (of politics) and were duly captured by regulated corporations. ${ }^{14}$ The neoliberal policy regime was a failed attempt to return to liberal capitalism, which, between the early nineteenth century and 1929, also produced slow growth, high financial instability, and deep inequality.

Thus, neoliberalism was most likely not a new stage of capitalist development. It was just a project aiming to reduce wage and non-wage labor costs by deregulating labor markets and seeking to reduce the social or welfare state. It was originally a response to the increasing power of the unions in the 1960s and to the new competition from developing countries exporting manufactured goods to rich countries from the 1970s. Although it preached the minimum state, it had only limited success in reducing the tax burden and the universal social and scientific services, because voters rejected these policies. As for regulation, it failed to reduce it except in the financial industry, where the 1986 "big bangs" in the United States and United Kingdom opened the way for high financial instability and the 2008 Global Financial Crisis. In many areas, regulation increased in the neoliberal years of capitalism. ${ }^{15}$

\footnotetext{
${ }^{14}$ It is interesting that the critique of the capture of the regulators by the regulated was made by an outstanding economist of the University of Chicago, George Stigler, one of the founders of the Mont Pelerin Society. Stigler was concerned with the regulation of relatively competitive industries. Yet, when neoliberalism created an opportunity for the privatization of monopolistic or quasi-monopolistic industries, neoclassical economists and neoliberal ideologues transformed the regulatory agencies into the perfect regulatory solution for the non-competitive sector, assuming that they would be able to define prices as if a market was in place.

${ }^{15}$ For instance, according to The Economist (July 13, 2013), the number of pages of federal taxes rules in the US was 16,500 in 1969 and had reached 72,536 pages by 2011.
} 
Markets are an excellent institution, but the only thing that they do well is coordinate competitive activities. Given the size and complexity of the major modern economies, given the existence of non-competitive industries, given the repeated failure of markets to establish the right macroeconomic prices, neoliberalism cannot be a stage of capitalism. It suffered a definitive defeat in 2008, which could have opened the way for a new and progressive developmentalism. What we see is a shy and conservative developmentalism - but I leave this discussion to other occasion. In this paper, my objective has been to oppose the concepts of the developmental state and developmental capitalism to the liberal state and liberal capitalism; to show that capitalism was born developmental as all industrial revolutions happened within the framework of developmental capitalism; and to argue that developmentalism is superior to economic liberalism in coordinating capitalist economies. It is certain that, under a liberal policy regime, a developing country will not grow satisfactorily and with financial stability; it will go from financial crisis to financial crisis as liberal policymakers defend the policy of growth with foreign savings. A developmental policy regime would do a much better job, provided that it can count on the support of a developmental class coalition and on capable administration.

\section{REFERENCES}

Aglietta, Michel ([1976]1982) Régulation et Crises du Capitalisme, Paris: Calmann-Lévy.

Aglietta, Michel (1995) Macroéconomie Financière, Paris: La Découverte.

Albert, Michel (1991) Capitalisme contre Capitalisme, Paris: Éditions du Seuil.

Bagchi, Amiya Kumar (2000) "The past and the future of the developmental state", Journal of World-Systems Research 6 (2): 398-442.

Berlin, Isaiah (1958 [1969]) "Two concepts of liberty", in Isaiah Berlin (1969) Four Essays on Liberty, Oxford: Oxford University Press. Original publication, 1958.

Boyer, Robert (2000) "Is a finance led growth regime a viable alternative to Fordism? A preliminary analysis", Economy and Society 29 (1): 111-145.

Boyer, Robert (2004) Une Théorie du Capitalisme: Est-elle Possible? Paris: Odile Jacob.

Bresser-Pereira, Luiz Carlos (2001) "The new left viewed from the south", in Anthony Giddens, ed. (2001) The Global Third Way Debate, Cambridge: Polity Press: 258-371.

Bresser-Pereira, Luiz Carlos (2010a) Globalization and Competition, New York: Cambridge University Press.

Bresser-Pereira, Luiz Carlos (2010b) "The global financial crisis, neoclassical economics, and the Neoliberal Years of Capitalism”, Revue de la Régulation 7, $1^{\text {st }}$ semester: 1-29.

Bresser-Pereira, Luiz Carlos (2014) "The hegemony constraints in the neoliberal years of capitalism", in Hideko Magara, ed. (2014) Economic Crises and Policy Regimes: The Dynamics of Policy Innovation and Paradigmatic Change, London: Edward Elgar: 56-78.

Bresser-Pereira, Luiz Carlos (2016) "Models of developmental state”, Discussion Paper EESP/FGV n. 426, September.

Bresser-Pereira, Luiz Carlos; José Luis Oreiro; Nelson Marconi (2014) Developmental Macroeconomics, London: Routledge.

Chesnais, François (1994) La Mondialisation du Capital, Paris: Syros.

Constant, Benjamin (1814 [1997]) “De l'esprit de conquête et de l'usurpation”, in Benjamin Constant (1997) Écrits Politiques, Paris: Gallimard. Original publication, 1814. 
Epstein, Gerald A., ed. (2005) Financialization and the World Economy, Cheltenham: Edward Elgar.

Evans, Peter (1992) "The state as problem and solution: Predation, embedded autonomy, and structural change”, in Stephan Haggard \& Robert Kaufman, eds. The Politics of Economic Adjustment, Princeton: Princeton University Press, 1992.

Fonseca, Pedro Cezar Dutra (2013 [2015]) "Desenvolvimentismo: a construção do conceito". In Ricardo Dathein, org. Desenvolvimentismo: o conceito, as bases teóricas e as políticas. Porto Alegre: Editora UFRGS, 2015: 13-72. Publicação original como Texto para Discussão IPEA, 2013.

Fourastié, Jean (1979) Les Trente Glorieuses, Paris: Fayard.

Gellner, Ernest (1983) Nations and Nationalism. Ithaca: Cornell University Press. 5nac

Giddens, Anthony (1998) The Third Way: The Renewal of Social Democracy, Cambridge: Polity.

Guttmann, Robert (2008) “A primer on finance-led capitalism and its crisis”, Revue de la Régulation $\mathrm{n}$. $3 / 4$, second semester: digital edition, no page numbers.

Guttmann, Robert (2016) Finance-Led Capitalism: Shadow banking, Re-Regulation, and the Future of Global Markets, New York: Palgrave MacMillan.

Ianoni, Marcus (2014) “Teoria do Estado desenvolvimentista: uma revisão da literatura” [Theory of the developmental state: a survey of the literature], Sinais Sociais 24: 81-106.

Jaguaribe, Hélio (1962 [1968)] Economic and Political Development, Cambridge: Harvard University Press. Original Portuguese publication, 1962.

Johnson, Chalmers (1982) MITI and the Japanese Miracle, Stanford: Stanford University Press.

Johnson, Chalmers (1999) “The developmental state: odyssey of a concept”, in Meredith Woo-Cummings, ed. (1999) The Developmental State, Ithaca: Cornell University Press: 32-60.

Manoilescu, Mihail (1929) Théorie du Protectionnisme et de l'Échange International, Paris: Giard.

Marglin, Stephen A. and Juliet B. Schor, eds. (1990) The Golden Age of Capitalism, Oxford: Clarendon Press: $1-38$.

Polanyi, Karl (1944 [1957]) The Great Transformation, Boston: Beacon Press. Originally published, 1944

Przeworski, Adam (2001) “How many ways can be third?”, in Andrew Glyn, ed. (2001) Social Democracy in Neoliberal Times, Oxford: Oxford University Press: 312-333.

Rosanvallon, Pierre (2011) La Société des Egaux, Paris: Seuil.

Sartori, Giovanni (1970) "Concept misformation in comparative politics", American Political Science Review 64: 1033-1035.

Schmitter, Philippe C. (1974) “Still a century of corporatism?”, Review of Politics 36(1): 85-131. Reproduzido in P. Schmitter e G. Lembruch, orgs (1979) Trends toward Corporatist Intermediation, Beverly Hills \& Londres, Sage Publications. : 7-52.

Shonfield, Andrew (1969) Modern Capitalism, Oxford: Oxford University Press.

Taylor, Charles (1995) Philosophical Arguments, Cambridge: Cambridge University Press.

Wallerstein, Immanuel (1980) The Modern World-System II: Mercantilism and the Consolidation of the European World-Economy, 1600-1750, London: Academic Press.

Walzer, Michael (1983) Spheres of Justice: A Defense of Pluralism and Equality. New York: Basic Books. 